\title{
Corporate Tax Avoidance and Firm Profitability
}

Naiping Zhu (PhD)

School of Finance and Economics, Jiangsu University, P R China

Nancy Mbroh

School of Finance and Economics, Jiangsu University, P R China

Finance Section, University of Education Winneba, Ghana.

\section{Augustine Monney (PhD Candidate)}

IT Services Directorate, University of Education Winneba, Ghana.

\section{Mandella Osei-Assibey Bonsu}

School of Finance and Economics, Jiangsu University, P R China

\begin{abstract}
The idea of trying to reduce an organization's tax expense is considered as old as the inception of taxation itself as organizations are always trying to exploit loopholes in the complexities of the existing tax system. The traditional motive for such practices is to reduce expenses, thereby increasing the firm's net profit. In view of this, tax avoidance has always been considered as being in the interest of the shareholders, as it is intended to increase value. However, this view has greatly been questioned in recent researches. Taking data from the annual reports and financial statements of firms listed on the Ghana Stock Exchange (GSE), we empirically tested whether tax avoidance of a firm really translates to increase in value or profitability. Employing a standard Ordinary Least Square regression model, we test our hypotheses using SPSS statistical tools. Our findings confirmed a negative relationship between the tax avoidance measure (ETR) and the measure of profitability (ROA). We conclude that tax avoidance could translate into profitability or value due to the balance of expertise and professionalism exhibited. We recommend that a firm need to have a good corporate governance structure in place, particularly the board structure, since they are in a better position to influence management's decisions and actions, in order to achieve the intended benefits of such practices.
\end{abstract}

Keywords: Corporate Tax Avoidance; Value Maximization; Under sheltering puzzle 


\section{Introduction}

Taxation is used as a tool of fiscal policy in controlling a country's economy (Nwaobia, Kwarbai, \& Ogundajo, 2016). It has also been used as a means of encouraging the growth of certain sectors and infant industries as well as encouraging investments. These are achieved by way of charging low rates to enterprises within those industries and granting some tax holidays to up to as much as ten (10) years for enterprises such as those in Tree Cropping, Cattle Ranching among others (Income Tax Act, 2015-Act 896). Regardless of these, to other entities the tax regime serves as a disincentive. Certain major corporate entities are continuously faced with the challenge of paying rather high corporate taxes. The obvious effect being that it adds to creating a high cost structure, depleting the after tax income distributable to the owners/shareholders of the firm. In the quest to reduce taxation costs, firms employ all means/activity that are legally acceptable within the country to increase their tax efficiency, thereby reducing their Effective Tax Rate (ETR). The idea of tax avoidance is of great concern to the general public and not viewed lightly since it leads to a reduced tax income for the country which is used for the supply of social amenities.

According to Abdul Wahab and Holland (2012), Corporate Tax Avoidance is a term used to refer to all activities undertaken by firms to gain a tax benefit or increase tax efficiency (Abdul Wahab \& Holland, 2012). Tax planning is traditionally viewed as being in the interest of shareholders since its aim is to cut down cost and increase the after tax profit. However, there have been opposing views on this notion. According to Armstrong et al (2015), the relationship between tax avoidance and value is not a straight line kind of relationship. It increases value in the form of positive net benefits (short term cash savings) but up to a maximum point beyond which the benefits derived from these activities becomes lesser than the costs involved and thus leads to fall in value. This phenomenon has been classified as the "under sheltering puzzle" by (Weisbach, 2001). In many researches about the value maximizing effects of tax avoidance activities, prior researchers suggest taking the governance structures into consideration in order to achieve the intended benefits of tax avoidance activities (Desai \& Dharmapala, 2006; Wilson, 2009). Nwaobia Appolos et al (2016) reported variations in the value maximizing effects of corporate tax avoidance among Nigerian manufacturing companies (Nwaobia et al., 2016). According to them, they found that the variations were due to differences in the governance structures of the companies and their use of knowledgeable professional experts. Drawing data from GSE listed firms, we test to assess whether corporate tax avoidance translates to increase in value and profitability in Ghanaian firms. 


\section{Literature/Theoretical underpinning \\ Corporate tax avoidance and firm financial performance}

Tax planning/avoidance is viewed as a term to refer to strategized activities put in place in order to earn a tax benefit, being in the form of temporal tax benefits (Temporal Differences) or permanent tax benefits (Permanent Differences), with most firms preferring a permanent difference since temporal differences does not have an overall impact on the firm's tax burden in the long run although yielding short term cash flow benefits (Abdul Wahab \& Holland, 2012) (Maydew \& Shackelford, 2005; Wilson, 2009).

Traditionally, since the intention for engaging in tax avoidance is to reduce cost in the form of tax and maintain value, it is viewed as being in the interest of shareholders. However, research has shown that firms tend to have some tax avoidance related costs in hind sight in their efforts to earn such tax benefits. Thus, preventing the full realization of the intended benefits. Weisbach (2002) classifies this phenomenon as the "under sheltering puzzle". According to Armstrong et al. (2015), benefits derived from tax avoidance does not have a linear relationship, but can be achieved up to an optimal level, beyond which tax avoidance related costs (e.g. costs of structuring complicated tax transactions, regulatory and reputational costs etc.) begins to exceed the benefits derived thereof(Armstrong, Blouin, Jagolinzer, \& Larcker, 2015). Desai \& Dhamapala (2006) argue that in a firm where there exists an information asymmetry (moral hazard), managers have a cover-up and tend to hide their self-seeking intentions for engaging in corporate tax avoidance, increasing the agency costs apart from the salaries and fees that are related to the tax avoidance activities. Thus, mitigating the value effects intended of the tax avoidance activities. In buttressing this and for shareholders to have control over managers' tax planning decisions, Slemrod (2004) suggests that managers' compensation ought to be linked with desired outcomes, for example, linked to a desired Effective Tax Rate (ETR) (Slemrod, 2004).

There has been a lot of research on the subject (for instance by Zimmerman (Zimmerman, 1983); Gupta \& Newberry (Gupta \& Newberry, 1997); (Holland, 2010)etc.) and through their work tried to explain the possible reasons for differences in tax burdens based on the characteristics of the firm. The direction of research in this area has quite recently shifted into understanding the reasons for such differences and its potential effect on the overall firm value. Some studies on the value effects of tax planning found no direct link between measures of firm value and tax planning measures. (Cloyd, Mills, \& Weaver, 2003) argue that this opposing view could be due to non-tax costs that cannot be quantified. However, other researchers on the subject like (Desai \& Dharmapala, 2009) suggest that in an agency setting, tax planning may potentially lead to a fall in firm value, particularly when there exists information asymmetry. 
In analyzing the potential effects of agency costs in mitigating the desired benefits or results from tax planning or avoidance worthy of consideration is the firm's existing governance structure/corporate design. This is because agency problems exist or persist in a firm due to its governance structure. According to (Castellini \& Riso, 2016), agency costs particularly increases in situations where the separation in ownership and control is wider. In extant literature on the subject, major mechanisms considered effective by researchers include the ownership structure, the board structure and the compensation scheme/structure in place (Florackis, 2008); (Mcknight \& Weir, 2009). In most prior researches on the subject, most researchers have focused attention on just an aspect of corporate governance. However, it has been suggested that this does not capture the overall strength and complexity of a firm's corporate governance structure in place, as corporate governance is quite broad a phenomenon (Jiménez-Angueira, 2018).

\section{Methodology \\ Sample and Data}

We take a sample of GSE listed firms and draw data from multiple firm year observations to make our empirical analyses. We use only GSE listed firms due to the uniformity in reporting requirements and availability of information. Data for this study were collected by analyzing and hand collecting vital information disclosed in the firm's annual report and financial statement. We employ the purposive sampling technique to screen down the firms such as financial firms, firms with losses reported in the period under consideration, firms with extreme ETRs etc.

\section{Variables}

\section{Independent and Control Variables}

The independent variable, the measure of Corporate Tax avoidance in the firm denoted by CTA, is a proxy measure of the firm's Effective Tax Rate (ETR) measured as the tax expense divided by the profit before tax. We control for firm size, leverage, capital intensity, inventory intensity, and board independence. These control variables have been shown in extant works to have effects on a firm's corporate tax avoidance behaviors. They are measured as shown in table 1 ;

Table 1 Measurements of control variables

\begin{tabular}{lll}
\hline Variable & Abbreviation & Measure \\
\hline Size & Size & Natural logarithm of total assets \\
Leverage & Lev & Long-term debt divided by total assets \\
Capital Intensity & Capint & Property, plant and equipment divided by total assets \\
Inventory & Invint & Inventory divided by total assets \\
$\begin{array}{l}\text { Intensity } \\
\text { Board } \\
\text { independence }\end{array}$ & Bind & Proportion of independent board members \\
\hline
\end{tabular}




\section{Dependent Variable}

The dependent variable is the measure of the firm's profitability, depicted by the measure of the firm's return on assets, which is measured as net after-tax profit divided by total assets.

\section{Regression Model}

We present the firms profitability as a function of its dependence on the profit before tax, tax avoidance measure and the control variables. The model is as follows;

FirmProfitability $_{i t}=\beta_{0}+\beta_{1} P B T_{i t}+\beta_{2}$ CT $_{i t}+\beta_{3-}$ Lcontrols $_{i t}+\varepsilon_{i t}$ where CTA is the corporate tax avoidance proxy measure of ETR (either Accounting ETR or Cash ETR), PBT is profit before tax and $\varepsilon$ is the error.

\section{Results/Findings and Discussions Descriptive Statistics}

Table 2 Descriptive Statistics

\begin{tabular}{|c|c|c|c|c|c|c|c|}
\hline & \multirow{2}{*}{$\begin{array}{c}\mathrm{N} \\
\text { Statistic }\end{array}$} & \multirow{2}{*}{$\begin{array}{c}\text { Minimum } \\
\text { Statistic }\end{array}$} & \multirow{2}{*}{$\begin{array}{l}\text { Maximum } \\
\text { Statistic }\end{array}$} & \multicolumn{2}{|c|}{ Mean } & \multirow{2}{*}{$\begin{array}{l}\text { Std. Deviation } \\
\text { Statistic }\end{array}$} & \multirow{2}{*}{$\begin{array}{l}\text { Variance } \\
\text { Statistic }\end{array}$} \\
\hline & & & & Statistic & Std. Error & & \\
\hline ROA & 104 & -.02 & .52 & .0812 & .00822 & .08384 & .007 \\
\hline PBTs & 104 & $1.89 E-003$ & 15.21 & .3616 & .14545 & 1.48332 & 2.200 \\
\hline ETR1 & 104 & 3.01E-003 & .73 & .2496 & .01092 & .11140 & .012 \\
\hline ETR2 & 104 & $1.46 \mathrm{E}-003$ & .91 & .2326 & .01321 & .13476 & .018 \\
\hline SIZE & 104 & 9.16 & 19.71 & 14.8249 & .24116 & 2.45937 & 6.048 \\
\hline LEV & 104 & $0.00 \mathrm{E}+000$ & 1.00 & .0701 & .01194 & .12179 & .015 \\
\hline CAPINT & 104 & $1.76 \mathrm{E}-004$ & .77 & .2281 & .02010 & .20495 & .042 \\
\hline INVINT & 104 & .00 & .58 & .1512 & .01127 & .11489 & .013 \\
\hline BIND & 104 & .10 & .92 & .7552 & .01607 & .16386 & .027 \\
\hline $\begin{array}{l}\text { Valid N } \\
\text { (listwise) }\end{array}$ & 104 & & & & & & \\
\hline
\end{tabular}

Table 2 presents the descriptive statistics for the data used for the study. The dependent variable ROA has a minimum of -0.02 and maximum of 0.52. The independent variables ETR 1 and ETR 2 both have minimums of $3.01 \mathrm{E}-003$ and 1.46E-003 respectively, with maximums of 0.73 and 0.91 respectively. The descriptive statistics for the control variables are presented in Table 2. 
Table 3 Correlations

\begin{tabular}{|c|c|c|c|c|c|c|c|c|c|c|}
\hline & & ROA & PBTs & ETR1 & ETR2 & $\begin{array}{c}\text { SIZ } \\
\text { E }\end{array}$ & LEV & $\begin{array}{c}\text { CAPIN } \\
\mathrm{T} \\
\end{array}$ & INVINT & BIND \\
\hline \multirow{3}{*}{ ROA } & $\begin{array}{c}\text { Pearson } \\
\text { Correlation }\end{array}$ & 1 & $.251^{*}$ & $-.216^{*}$ & $-.231^{*}$ & -.169 & .100 & .146 & .067 & .014 \\
\hline & Sig. (2-tailed) & & .010 & .028 & .018 & .086 & .311 & .141 & .497 & .886 \\
\hline & $\mathrm{N}$ & 104 & 104 & 104 & 104 & 104 & 104 & 104 & 104 & 104 \\
\hline \multirow{3}{*}{ PBTs } & $\begin{array}{l}\text { Pearson } \\
\text { Correlation }\end{array}$ & $.251^{*}$ & 1 & $-.215^{*}$ & -.157 & .085 & -.031 & -.071 & -.120 & .029 \\
\hline & Sig. (2-tailed) & .010 & & .029 & .112 & .390 & .753 & .471 & .224 & .771 \\
\hline & $\mathrm{N}$ & 104 & 104 & 104 & 104 & 104 & 104 & 104 & 104 & 104 \\
\hline \multirow{3}{*}{ ETR1 } & $\begin{array}{l}\text { Pearson } \\
\text { Correlation }\end{array}$ & $-.216^{*}$ & $-.215^{*}$ & 1 & $.325^{* *}$ & -.056 & -.020 & .137 & .130 & .189 \\
\hline & Sig. (2-tailed) & .028 & .029 & & .001 & .574 & .843 & .165 & .189 & .055 \\
\hline & $\mathrm{N}$ & 104 & 104 & 104 & 104 & 104 & 104 & 104 & 104 & 104 \\
\hline \multirow{3}{*}{ ETR2 } & $\begin{array}{l}\text { Pearson } \\
\text { Correlation }\end{array}$ & $-.231^{*}$ & -.157 & $.325^{* *}$ & 1 & -.177 & -.030 & -.134 & -.021 & .070 \\
\hline & Sig. (2-tailed) & .018 & .112 & .001 & & .073 & .762 & .174 & .830 & .478 \\
\hline & $\mathrm{N}$ & 104 & 104 & 104 & 104 & 104 & 104 & 104 & 104 & 104 \\
\hline \multirow{3}{*}{ SIZE } & $\begin{array}{l}\text { Pearson } \\
\text { Correlation }\end{array}$ & -.169 & .085 & -.056 & -.177 & 1 & -.038 & $-.359^{* *}$ & .186 & .147 \\
\hline & Sig. (2-tailed) & .086 & .390 & .574 & .073 & & .702 & .000 & .058 & .137 \\
\hline & $\mathrm{N}$ & 104 & 104 & 104 & 104 & 104 & 104 & 104 & 104 & 104 \\
\hline \multirow{3}{*}{ LEV } & $\begin{array}{l}\text { Pearson } \\
\text { Correlation }\end{array}$ & .100 & -.031 & -.020 & -.030 & -.038 & 1 & -.020 & $-.264^{* *}$ & -.059 \\
\hline & Sig. (2-tailed) & .311 & .753 & .843 & .762 & .702 & & .837 & .007 & .550 \\
\hline & $\mathrm{N}$ & 104 & 104 & 104 & 104 & 104 & 104 & 104 & 104 & 104 \\
\hline \multirow{3}{*}{$\begin{array}{l}\text { CAPI } \\
\text { NT }\end{array}$} & $\begin{array}{l}\text { Pearson } \\
\text { Correlation }\end{array}$ & .146 & -.071 & .137 & -.134 & $\begin{array}{r}.359^{*} \\
*\end{array}$ & -.020 & 1 & .153 & .190 \\
\hline & Sig. (2-tailed) & .141 & .471 & .165 & .174 & .000 & .837 & & .120 & .053 \\
\hline & $\mathrm{N}$ & 104 & 104 & 104 & 104 & 104 & 104 & 104 & 104 & 104 \\
\hline \multirow{3}{*}{$\begin{array}{c}\text { INVIN } \\
\mathrm{T}\end{array}$} & $\begin{array}{l}\text { Pearson } \\
\text { Correlation }\end{array}$ & .067 & -.120 & .130 & -.021 & .186 & $.264^{*}$ & .153 & 1 & -.110 \\
\hline & Sig. (2-tailed) & .497 & .224 & .189 & .830 & .058 & .007 & .120 & & .265 \\
\hline & $\mathrm{N}$ & 104 & 104 & 104 & 104 & 104 & 104 & 104 & 104 & 104 \\
\hline \multirow{3}{*}{ BIND } & $\begin{array}{l}\text { Pearson } \\
\text { Correlation }\end{array}$ & .014 & .029 & .189 & .070 & .147 & -.059 & .190 & -.110 & 1 \\
\hline & Sig. (2-tailed) & .886 & .771 & .055 & .478 & .137 & .550 & .053 & .265 & \\
\hline & $\mathrm{N}$ & 104 & 104 & 104 & 104 & 104 & 104 & 104 & 104 & 104 \\
\hline
\end{tabular}

*. Correlation is significant at the 0.05 level (2-tailed).

**. Correlation is significant at the 0.01 level (2-tailed).

\section{Correlation Analyses}

The Correlation analyses results are presented in Table 3. From the results, it is clear that both measures of corporate tax avoidance (ETR 1 and ETR 2) have significant correlation with the dependent variable ROA with 
negative correlations of -0.216 and -0.231 respectively. This negative correlation is an indication that as corporate tax avoidance is increasing in a firm it translates to profitability since a lower ETR is an indication of higher tax avoidance in the firm. The correlations for the other variables are presented in Table 3.

Table 4 Coefficients ${ }^{\mathrm{a}}$

\begin{tabular}{|c|c|c|c|c|c|c|}
\hline & \multirow[t]{2}{*}{ Model } & \multicolumn{2}{|c|}{$\begin{array}{c}\text { Unstandardized } \\
\text { Coefficients }\end{array}$} & \multirow{2}{*}{$\begin{array}{c}\begin{array}{c}\text { Standardized } \\
\text { Coefficients }\end{array} \\
\text { Beta }\end{array}$} & \multirow[t]{2}{*}{$\mathrm{t}$} & \multirow[t]{2}{*}{ Sig. } \\
\hline & & B & Std. Error & & & \\
\hline \multirow{8}{*}{1} & (Constant) & .157 & .061 & & 2.591 & .011 \\
\hline & PBTs & .014 & .005 & .254 & 2.671 & .009 \\
\hline & ETR1 & -.171 & .073 & -.227 & -2.338 & .021 \\
\hline & SIZE & -.008 & .004 & -.230 & -2.145 & .034 \\
\hline & LEV & .109 & .066 & .159 & 1.656 & .101 \\
\hline & CAPINT & .026 & .044 & .063 & .587 & .558 \\
\hline & INVINT & .156 & .076 & .214 & 2.045 & .044 \\
\hline & BIND & .054 & .052 & .105 & 1.034 & .304 \\
\hline
\end{tabular}

a. Dependent Variable: ROA

Table 5 Coefficients ${ }^{\mathrm{a}}$

\begin{tabular}{ccccccc}
\hline \multirow{2}{*}{ Model } & \multicolumn{2}{c}{$\begin{array}{c}\text { Unstandardized } \\
\text { Coefficients }\end{array}$} & $\begin{array}{c}\text { Standardized } \\
\text { Coefficients }\end{array}$ & $\mathrm{t}$ & Sig. \\
\cline { 3 - 5 } & & $\mathrm{B}$ & Std. Error & Beta & & \\
\hline \multirow{4}{*}{1} & (Constant) & .189 & .064 & & 2.945 & .004 \\
& PBTs & .015 & .005 & .262 & 2.787 & .006 \\
& ETR2 & -.150 & .061 & -.241 & -2.459 & .016 \\
& SIZE & -.010 & .004 & -.287 & -2.581 & .011 \\
& LEV & .102 & .066 & .149 & 1.553 & .124 \\
& CAPINT & -.007 & .045 & -.018 & -.162 & .871 \\
& INVINT & .146 & .076 & .200 & 1.930 & .057 \\
& BIND & .051 & .051 & .100 & .995 & .322 \\
\hline
\end{tabular}

a. Dependent Variable: ROA

\section{Regression Results}

Table 4 and 5 presents the regression results using both ETR 1 and ETR 2 interchangeable as the independent variable. From the results of the first regression analyses presented in Table 4(ETR 1 as independent variable), we find significant and negative influence of ETR 1 and SIZE on ROA with $t$ values of -2.338 and -2.145 respectively, and significant positive influence of PBTs and INVINT with $t$ values of 2.671 and 2.045 respectively. The Beta coefficients are presented in Table 4. Using ETR 2 as the dependent variable for the second regression analyses (results in Table 5), ETR 2 and SIZE measure significant and negative influence with ROA with $t$ values of -2.459 and -2.581 , and PBTs measures a positive significant influence on ROA with 
$t$ value of 2.787. The Beta coefficients and the results of for the other variables are presented in Table 5.

\section{Conclusion}

As earlier discussed, there has been a lot of debate as to whether tax avoidance actually results in improving the firm's value or the firm's profitability. It is traditionally viewed that tax avoidance, since it is aimed at reducing expenses and increasing net after tax profit, enhances value and profitability. However, recent researchers have argued from empirical points that corporate tax avoidance does not translate to profitability or value maximization, this phenomena being argued as being the result of the corporate governance system in place. In our results, we found a significant negative relationship between the measure of profitability (ROA) and the measures of Corporate Tax Avoidance (ETR 1, ETR 2). Since a low ETR is an indication of a higher corporate tax avoidance within a firm, our findings imply that corporate tax avoidance in fact does translate to profitability and value.

We conclude that corporate tax avoidance translates to profitability or value maximization, as was intended, when the firm has to its advantage a balance of expertise and professionalism by those entrusted in the hem of affairs of the firm, that is, the management. In a nutshell, there has to be a good corporate governance system in place to be able to put managers' decisions in check in order for tax avoidance to result in the intended gain.

\section{Future Research}

Further research should focus on analyzing the interplay of other complex factors that are linked to tax avoidance behaviors in firms especially in Ghana.

\section{Acknowledgement}

This paper is supported by China's Ministry of Education in the humanities and social sciences research planning fund project (16YJA860015).

\section{References:}

1. Abdul Wahab, N. S., \& Holland, K. (2012). Tax planning, corporate governance and equity value. The British Accounting Review, 44(2), 111-124. doi:https://doi.org/10.1016/j.bar.2012.03.005

2. Armstrong, C. S., Blouin, J. L., Jagolinzer, A. D., \& Larcker, D. F. (2015). Corporate governance, incentives, and tax avoidance. Journal of Accounting and Economics, 60(1), 1-17. doi:https://doi.org/10.1016/j.jacceco.2015.02.003 
3. Castellini, M., \& Riso, V. (2016). Agency Theory Applied to the Italian Revenue Agency: Accountability Policies as Bonding Costs. European Scientific Journal, ESJ, 12(34), 1.

4. Cloyd, C. B., Mills, L. F., \& Weaver, C. D. (2003). Firm Valuation Effects of the Expatriation of U.S. Corporations to Tax-Haven Countries. The Journal of the American Taxation Association, 25(s-1), 87-109. doi:10.2308/jata.2003.25.s-1.87

5. Desai, M. A., \& Dharmapala, D. (2006). Corporate tax avoidance and high-powered incentives. Journal of Financial Economics, 79(1), 145179. doi:https://doi.org/10.1016/j.jfineco.2005.02.002

6. Desai, M. A., \& Dharmapala, D. (2009). Corporate Tax Avoidance and Firm Value. The Review of Economics and Statistics, 91(3), 537-546. doi:10.1162/rest.91.3.537

7. Florackis, C. (2008). Agency costs and corporate governance mechanisms: evidence for UK firms. International Journal of Managerial Finance, 4(January), 37-59.

8. Gupta, S., \& Newberry, K. (1997). Determinants of the variability in corporate effective tax rates: Evidence from longitudinal data. Journal of Accounting and Public Policy, 16(1), 1-34. doi:https://doi.org/10.1016/S0278-4254(96)00055-5

9. Holland, K. (2010). Accounting Policy Choice: The Relationship Between Corporate Tax Burdens and Company Size. Journal of Business Finance \& Accounting, 25(3\&4), 265-288.

10. Jiménez-Angueira, C. E. (2018). The effect of the interplay between corporate governance and external monitoring regimes on firms' tax avoidance. Advances in Accounting, 41, 7-24. doi:https://doi.org/10.1016/j.adiac.2018.02.004

11. Maydew, E. L., \& Shackelford, D. A. (2005). The Changing Role of Auditors in Corporate Tax Planning. Nber Working Papers, 21(1), 307-344.

12. Mcknight, P. J., \& Weir, C. (2009). Agency costs, corporate governance mechanisms and ownership structure in large UK publicly quoted companies: A panel data analysis. Quarterly Review of Economics \& Finance, 49(2), 139-158.

13. Nwaobia, A., Kwarbai, J., \& Ogundajo, G. (2016). Tax Planning and Firm Value: Empirical Evidence from Nigerian Consumer Goods Industrial Sector (Vol. 7).

14. Slemrod, J. B. (2004). The Economics of Corporate Tax Selfishness. Joel Slemrod, 57(4), 877-899.

15. Weisbach, D. A. (2001). Ten Truths about Tax Shelters. Ssrn Electronic Journal, 55(2). 
16. Wilson, R. J. (2009). An Examination of Corporate Tax Shelter Participants. Accounting Review, 84(3), 969-999.

17. Zimmerman, J. L. (1983). Taxes and firm size. Journal of Accounting and Economics, 5, 119-149. doi:https://doi.org/10.1016/0165$\underline{4101(83) 90008-3}$ 